\title{
THE MUTUAL FUND MANAGEMENT FEE
}

\section{INTRODUCTION}

Professor Robert H. MundHeim: This afternoon we depart from the more academic subject of this morning's discussion, and talk about money issues. The Commission's recommendations in this area, if accepted, presumably would lower the cost to the investing public of investing in mutual funds and correspondingly would reduce the profits of those who sponsor mutual funds.

We shall look first at the problem of management fees-the amounts paid by mutual funds for investment advisory and administrative services. The Commission's conclusion in the area is that investors in mutual fund shares have not benefited sufficiently from the economies of size which are characteristic of the industry. ${ }^{1}$

In addition the Commission has concluded that if the public is to get a fair share of these economies of size, there is a need for greater involvment by an outside force-ultimately, a court-in setting proper levels for management fees. ${ }^{2}$ The normal bias in our economy is against interference by outside forces in the setting of prices. Thus, the burden would seem to be on the proponent of such interference to make a case for its necessity.

The Commission, which relies heavily on the Wharton School Study in this area, rests its case on a finding that competitive forces which normally exert restraints on prices do not operate effectively in the fee area. This means, on the one hand, that funds are not able to shop around for investment advice, and on the other, that the buying public is either unaware of the differences in the fees charged to various funds, or that the buying public does not have an opportunity to focus effectively on the management fee issue alone, because other features loom much larger at the time the investor makes his choice among various funds.

In Chapter III of its report, which deals with management fees, the Commission evaluates other potential restraints on the fees charged to the fund. The Commission focuses on the ability of the unaffiliated directors to exert an effective influence on management

1 Securities \& Exchange Comm'n, Public Policy Implications of Invesiment Company Growth, H.R. REP No. 2337, 89th Cong., 2d Sess. 11-12 (1966) [hereinafter cited as SEC Mutnal Find Report].

2 Id. at 13. 
fees and examines the efficacy of shareholder litigation. It found both of these restraints of minimal value. ${ }^{3}$

Thus, the Commission concluded that a new restraint was necessary. Its recommendation was that the Investment Company Act should be amended to provide that compensation paid for services furnished to a mutual fund must be reasonable. ${ }^{4}$ You must admit that there is a certain artistry in the way that is put, because if you don't agree with their recommendation, then you are forced to say that the fees should be unreasonable-and nobody would say that.

The Commission set out certain factors which should be considered in determining what is reasonable compensation. ${ }^{5}$ I hope that in the course of this afternoon's discussion we shall get some enlightenment on the meaning of the standards used in determining reasonable compensation. In addition, I hope we will be able to make some judgments about the extent to which the Commission has correctly analyzed the problem, and perhaps discuss some alternative ways of dealing with the kinds of problems, if any, which we can agree do exist.

\section{Findings of the Wharton School Study}

Since the Wharton School Study provides much of the material for the Commission's analysis in this field, I think it is appropriate to start by asking Professor Herman, who was one of the co-authors of the study, to begin our discussion.

Professor Edward S. Herman: Thank you, Mr. Chairman.

What I would like to do is outline briefly the factual basis for the criticisms of mutual fund management fee rates, as developed in the Wharton report and the SEC report, then comment very briefly on the industry replies to these criticisms, and finally offer a few comments on policy and standards.

In the Wharton School report we examined the management fee rates for externally managed mutual funds, for internally managed funds-funds managed by their own boards of directors or trustees without an external management-and for the noninvestment company clients of investment advisers who also managed mutual funds.

We were fortunate to have been able to collect information from at least fifty-four investment advisers who managed the assets of mutual funds and other clients. We had evidence on the expense 
ratios of these advisers for both classes of customers, and on the fee rates which they charged.

Our findings were roughly as follows: that the management fee rates of externally managed funds were significantly higher than those for internally managed funds, and very much higher than those charged noninvestment company clients at comparable asset levels. ${ }^{6}$ Also the rates of the externally managed funds were less responsive to variations in size, for all funds at a given time and for individual funds over time. ${ }^{7}$ In 1960, twenty-six of the forty largest investment advisers charged fees of one-half of one per cent or more. ${ }^{8}$ And in 1960 there was no statistically significant relationship between the size of the fund and the management fee rate charged. ${ }^{9}$

Also, as I mentioned, we found that over time the management fee rates didn't change very much, regardless of asset changes. There were a number of cases of asset changes of 500 per cent or more over the 'fifties which produced no change in the management fee rate. ${ }^{10}$ The rates for the externally managed funds were especially unresponsive to changes in size, remaining very heavily concentrated around the traditional one-half of one per cent level. ${ }^{11}$

We then asked this question: Can the greater amount and the lesser flexibility of the rates of the externally managed funds be explained by the services they perform or by the costs that they incur in managing these assets? This, of course, would not explain any difference between externally and internally managed funds, since they both are mutual funds, and the nature of the expenses which are incurred are comparable.

For the management fee rate we made an analysis in which we imputed to the internally managed funds the costs of services comparable to those provided by the externally managed funds. The costs for the internally managed funds were significantly lower. ${ }^{12} \mathrm{We}$ found that on the basis of a detailed study of the expenses of investment advisers that as the size of assets managed increased, the expense ratios of the adviser fell substantially. The sharpest decrease in expense ratio was experienced by investment advisers who only had investment company clients. The economies of scale for fifty-four

${ }^{6}$ Wharton School of Finance and Commerce, A Study of Mutual Funds, H.R. ReP. No. 2274, 87th Cong., 2d Sess. 485-91 (1962) [hereinafter cited as Wharton Report].

7 Id. at $489-91$.

$8 I d$. at 482 .

9 Id. at 490 .

10 Ibid.

$11 \mathrm{Id}$. at 482-83, 490.

$12 I d$. at 485 . 
advisers who managed both mutual fund and noninvestment company assets were not as great as those for the investment advisers who only had investment company clients. ${ }^{13}$

\section{The Expense of Serving Mutual Funds Compared to Noninvestment Company Clients}

The most important of our findings regarding the fees charged mutual funds and noninvestment company clients concerns the relative expense of serving the two kinds of clients. In our study of the fifty-four investment advisers who had both mutual fund and noninvestment company clients, we found that the higher the proportion of noninvestment company assets managed, the higher the adviser's expense ratio. ${ }^{14}$ This conclusion and other statistical evidence seemed to demonstrate quite conclusively that mutual fund assets are less expensive to manage than the assets of other clients.

Now, this is entirely plausible, since mutual fund shareholders do not require individual portfolio attention or individual reports. Also, some of the major expenses of mutual fund administration, such as reports to shareholders, costs of annual meetings, transfer agent costs, dividend disbursing costs and custodial fees are typically absorbed by the fund and the shareholders, not by the investment adviser.

The evidence thus indicated that the cost to the investment advisers of managing mutual fund assets was less than that for managing comparable levels of assets for other clients. In spite of this, the management fees charged mutual funds tended to exceed those charged other clients by a large margin, frequently in excess of 100 per cent.

The SEC report extends our examination of the fee rates charged noninvestment company clients. The report indicates that the management costs of pension funds and other large clients are also substantially lower than those charged mutual funds of comparable size. ${ }^{15}$

I repeat this crucial conclusion from our study: the ordinary run of noninvestment company clients costs more per dollar to manage than do mutual funds. Also, the expenses of managing mutual funds falls sharply as their size increases. Therefore, the explanation for the higher and less flexible management fee rates of mutual funds must be found elsewhere than in expenses incurred or services rendered.

13 Id. at 499-503. Curiously, the expense ratios for advisers who managed mutual fund assets of over $\$ 300$ million were not necessarily less than the expense ratio for advisers who managed assets of about $\$ 300$ million.

14 Id. at 501-02.

15 SEC Mutual Fisud Report 114-21. 


\section{The Industry Justification for the Cost-Rate Discrepancy}

I have yet to see an industry explanation or justification of this cost-rate discrepancy. The typical response of the industry has avoided the substantive question of the cost-rate relationship and has concentrated on whether an individual shareholder could obtain a lower management fee rate through some other channel. This is the heart of the "emphatic rebuttal" to the SEC discussion of management fee rates just issued by Mr. Shelley of Vance, Sanders \& Co. ${ }^{16}$

The argument that the small shareholder "could not do better elsewhere," although worthy of note, really fails to come to grips with the central issues. If the mutual fund is a single account, managed as a single investment entity, why do the management fees which it pays fail to reflect observable cost variations? Mr. Shelley never answers this, and we are still waiting to hear a response to this point from the representatives of the industry.

Secondly, in considering the management contract, is the responsibility of a director of a fund exhausted when he has established that the shareholder, whose interests he is supposed to represent, has no better option? Presumably the director of the fund observes that expense ratios decline as asset size grows. He observes that there is a scaled rate for other clients. He observes that there is a difference between the fee rates charged other clients and the mutual fund, and still, presumably, he is supposed to conclude, according to Mr. Shelley's logic, that the management fee rate is satisfactory because the mutual fund shareholder could not do better anywhere else.

\section{The Relationship Between Industry Structure and Management Fees}

Let me offer an explanation for the behavior of the management fee rates in the mutual fund industry. Basically, the structure of the industry, with an external adviser and a mutual fund shell, seems to generate high rates. There is such a strong correlation between the existence of an external adviser and relatively high management fee rates that one must attribute the high rates, at least in part, to the existence of this structural characteristic of the industry.

This observation simply reports an empirical fact. The correlation between external advisers and high management fee rates may be explained by the ability of the external adviser relationship to hide a layer of relatively obscure income claimants. Furthermore, the external adviser-mutual fund relationship presents to the shareholder an unreal picture of fund independence and fund capacity to bargain.

Stripping away this shell, by forcing all the funds to be internally managed, would be a simple device which, of course, would be rather

16 Letter from William F. Shelley, January 26, 1967. 
drastic at this late stage in the industry's development, and I suspect that Mr. Welch would object to this solution. But it definitely would attack a structural characteristic of the industry that is generating high rates, and it would bring about a lowering of rates without the continuing intervention that otherwise might be necessary.

I am somewhat ambivalent about this solution because by itself it would not lower rates to the levels obtained by other large clients. The reason for this is that the high management fee rates are not solely a function of the organizational structure of the industry. They also reflect the inability of the small shareholder to bargain on this question, and I see no feasible way of improving his bargaining position. For this reason I would support the application of some sort of rule of reason, such as the SEC has proposed, as a kind of stand-by authority, with the standards presumably derived from the competitive rates that are established in those areas where there is a bargaining process that permits a truly negotiated rate.

\section{The Industry View of Management Fee Rates}

Professor Mundereim: Joe Welch, who is president of the Wellington Fund, has obviously had an inside view of how management fee rates are set, and I suppose that your views, Joe, differ somewhat from Ed's.

Mr. JoSEPH E. WELCH: You are entirely right, Bob. Mine are a little different.

My remarks are based on an assumption that we're still living in a free country with free enterprise, subject only to the proper rules and regulations to avoid and control abuses.

I'd like to say at the very outset that, certainly, I agree that management fees should be reasonable. It naturally follows, therefore, that I favor reductions in management fees through some form of sliding scale as funds grow in size. But, having said that, I must also say first, that I am strongly opposed to having management fees controlled, directly or indirectly, by a government agency, no matter how well intentioned that agency may be; second, that I see no need for such regulation. Remedies and safeguards to control excessive fees, in my judgment, already exist.

\section{The Nature of the Investment Adviser's Business}

The management of other people's money, whether directly for individual investors, or indirectly through a mutual fund, is a professional personal service business. It is highly competitive business. There is no monopoly. There is no limited right of entry. There 
is full disclosure of all costs, not only at the time of purchase of mutual fund shares, but at least three times every year thereafter through reports and proxy statements. Thus an investor has a wide choice of funds, not only with different objectives and investment policies, but also with different cost of management, which runs anywhere from an eighth of one per cent to one-half of one per cent.

I know of no instance where governmental control of rates has been imposed on a personal service industry that is as competitive as the mutual fund industry. Rather, I believe that the matter should be left to the natural forces of competition, which I am sure in time will cure any problems that may exist.

\section{The Argument Against Government Regulation of Fees}

$\mathrm{My}$ second point is that I feel there is no need for government regulation of management fees at this time. I say this, first of all, because the directors of mutual funds today, I believe, are fully aware of their responsibility to see to it that the manager properly performs the service he has contracted to perform, and that the fee paid for this service is reasonable. Evidence of the recognition of the responsibilities of directors is apparent, I think, in the meaningful reductions in management fees paid by most of the large funds. A recent tabulation by $\mathrm{Mr}$. Shelley, to which you referred, Ed, shows that of all of the funds with assets of $\$ 100$ million or over the average management fee is $37 / 100$ of 1 per cent-essentially three-eighths-and many of these companies have even lower rates. ${ }^{17} \mathrm{I}$ believe these rates will become even lower as more money comes in at the brackets where the sliding scales begin to take effect. And if this fact is not enough evidence of the responsibility-and the recognition of that responsibility-by directors, it must be remembered that if shareholders become dissatisfied with what their own directors are doing, they do have remedies through recourse to the courts, where the decision will be made as to whether or not the management fees that are paid are or are not excessive.

On this particular point, the long period of lawsuits throughout the industry, ${ }^{18}$ the publicity on the issuance of the Wharton School report and now the SEC report, have made all directors even more conscious of their responsibilities, and beyond that, the great risk that they run if they fail to discharge these responsibilities.

17 Id. at 1 .

18 The law suits attacking mutual fund fees are discussed in SEC Mutual Fund Report 132-43; Eisenberg \& Lehr, An Aspect of the Emerging "Federal Corporation Law": Directorial Responsibility Under the Investment Company Act of 1940, 20 RUtGers L. REv. 181 (1966). 
With these safeguards already available and becoming more forceful every day, I just cannot see the need for the legislative proposals with respect to management fees.

\section{Criteria for Measuring the Reasonableness of the Management Fee}

I would like to spend just a moment, Bob, if I may, on the report's suggestions as to the criteria to be used to measure whether or not management fees are reasonable. In other words, just what should a board of directors consider when they either renew a management contract or when they submit a new one for shareholder approval?

First of all, in my judgment, the directors should do just what Al Smith always recommended: look at the record. Thus they can see how well the fund has performed under the manager's guidance in the light of its stated objectives and investment policies. As was said here earlier this morning, that is the real test of performance: have you met the objectives of the fund in the light of its policies?

The board also should acquaint itself with the quality and depth of the management organization, and thus evaluate its ability to continue to provide competent management as people change from year to year, and to provide in future years competent service for the fund.

In reviewing the rate of a management fee these factors-the record, the quality and the depth of the management team-should be given great weight. The board should satisfy itself that the fee is reasonable when measured against the record and the cost of similar services that might be available to the average mutual fund investor.

And here I do depart from you somewhat, Ed, and your statement that a mutual fund is just one account to manage. This may be the legal interpretation, but $I$ think from a practical point of view we are managing, in our case, the money of 300-and-some-oddthousand individual accounts.

\section{The Management Fee Compared With Bank Charges}

The SEC report suggests a comparison with the cost of bank management of pension funds. ${ }^{19}$ Well, a lot has been said about that today, and I'm not going to elaborate, except to say that I do not believe this comparison is appropriate. I do, however, agree that comparisons with bank charges are perfectly valid, and would suggest a comparison with bank charges on their common trust funds, which are similar to mutual funds. 
As you all know, the bank common trust funds are designed to serve the small or modest-sized trust accounts, as mutual funds are designed primarily to serve the small investor. In these common trust funds the banks assess the management charge directly against the individual participant-the individual participating trust, if you will-which I think is an entirely appropriate way to do it.

In a publication which the Manufacturers Hanover Trust Company of New York released last year, there is included a scale of fees charged to the participants in its common trust funds. For an investment of $\$ 5,000$ the charge is 5 per cent, as compared to the average of $37 / 100$ of 1 per cent for the average mutual fund for an account of $\$ 10,000$ in size-which is the average holding of most mutual fund shareholders-the average charge is $2 \mathrm{I} / 2$ per cent, as compared to the $37 / 100$ that I mentioned earlier. Not until the participating trust reached the sum of $\$ 100,000$ or more would the fee charged by the bank against that particular trust be equal to the fees charged for a similar amount by the average mutual fund.

I have quoted the New York rate, which I believe is reduced somewhat by banks outside of New York; for example, in Boston the rate of charge at $\$ 5,000$ is just $11 / 2$ per cent; and at $\$ 10,000$, $85 / 100$ of 1 per cent.

Another meaningful comparison, I believe, would be the rate of the fee charged by the first bank-sponsored mutual fund to be registered with the SEC. Here the management fee is set at a straight one-half of one per cent, with no provision for reduction of the fee as the fund grows in size.

That charges made by banks provide a valid means of comparison is evidenced further, I believe, by the fact that the banks are the largest money managers, with total investment accounts of well over $\$ 100$ billion, perhaps nearly three times as much as the entire mutual fund industry put together.

But despite the fact that they are managing all of this money, if you or I were to walk into the trust department of a bank, with $\$ 10,000$ or $\$ 20,000$ or a little bit more, the fee that they would charge would be related to that particular amount of money, and would not be reduced because of the many billions of dollars that the bank also manages in its trust department. In other words, each account is treated individually and not as part of an aggregate.

\section{The Management Fee and Performance}

As I said at the outset, I believe that management fees should be reasonable, and I think they are reasonable when measured against 
the real test, which is the results achieved. For example, a recent publication by Arthur Wiesenberger \& Co. shows the relative performance of growth funds, growth and income funds and balanced funds for the last ten years. ${ }^{20}$ I calculated the performance of the Dow Jones Industrial Average for the same period and made the same adjustments Wiesenberger did for income. The results follow: for the ten-year period the Dow Jones Average showed a gain, adjusted for income, of 106 per cent. The outright growth funds showed an average gain of 153 per cent; the growth with income funds, 116 per cent; and the balanced funds, with between 30 and 40 per cent of their assets in senior securities showed a gain of 91 per cent.

Now, as I have said, the real test depends, in my judgment, upon the results achieved, and I believe that the performance record of mutual funds over the years has been excellent. For the average investor, in my judgment, three things are desirable: diversification, competent management and convenient services. Mutual funds make all of these desirable elements available in a wide variety of forms, each fully competitive with the other. I know of no other way in which an investor can obtain these services at such a reasonable cost.

To conclude, let me repeat again that management fees should be reasonable, that they should be reduced on a scale based on the growth in the size of the fund. I would strongly oppose, however, any effort to regulate management fees in a highly competitive business, and suggest that it is wrong for a government agency to substitute its own judgment for that of a competent board of directors. I really think that the record makes it clear that there is no need for legislation at this time.

\section{Is the Management Fee Affected by Competition?}

Professor Mundheim: As I listened to Joe and Ed, it seemed to me one area of dispute is whether or not there is competition that affects the compensation structure. Ed seems to think there isn't; Joe seems to think there is adequate competition and numerous alternatives. It is the existence of alternatives which Joe suggests justifies the existing structure and rates.

I wonder whether I could sound out the members of the panel as to how they feel about the ability of competition to work effectively in this area. Is the presence or absence of competition a factor of prime importance?

Mr. Allan F. Conwill: I'll undertake to answer that partially, Bob.

20 A. Wiesenderger \& Co., Investarent CoMpanies 1966 (26th ed. 1966). 
First of all, I think that the mutual fund industry, as such, is as intensely competitive as any industry I know. However, I do not believe that the management fee is really an element of the competition.

Joe Welch has pointed out to you what is quite true, that management costs are readily available and clearly disclosed to the stockholder. I rather doubt, however, if the stockholder pays a great deal of attention to them in making his investment decision. Indeed, I would surmise that Brother Pomerantz has had more to do with bringing the fee rates down than the competitive aspects.

Mr. Robert M. Loeffler: Competition is a difficult element to appraise. I think that competitive forces are at work on the management fee, and to that extent my view may be different from Allan's. It's a subtle influence, but it is there, and I think it is becoming increasingly important.

I don't have a lot of industry data available but I do have the data on IDS.

I think these figures show that developments in the fund industry are characteristic of any industry that is young and realizes a period of almost sensational growth. In the fund industry that growth commenced during the decade of the 'fifties.

Competitive forces come into play after the growth period. They don't coincide with this dramatic growth. I don't think the SEC report takes into account the developments and trends of the most recent few years. In deference to the gentleman on my left, $\mathrm{Mr}$. Pomerantz, I think I would have to acknowledge, as Allan did, that the commencement of the interplay of the competitive forces might have been triggered a little bit by him. But, having been triggered, I think they are working.

Let me take just these figures from IDS's standpoint for a moment. IDS manages four funds. One of them is a small bond and preferred fund, and I think I'll leave out the figures for that one, and take the other three.

Investors Mutual, had assets as of December 31, 1966 of $\$ 2,760,000,000$; Investors Stock Fund, had assets of $\$ 1,736,000,000$ and Investors Variable Payment, had assets of $\$ 588,000,000$. So I think we are talking about larger funds.

Investors Mutual was founded in 1940. Investors Stock Fund was founded in 1945. Investors Variable Payment Fund began its operations in 1957. The growth of these funds has been great, as evidenced by their present size.

There was no change in the management contracts of these funds, as they related to management fees, until the impact of the sensational 
growth of the 1950's was fully realized in the early 1960's, and Mr. Pomerantz came on the scene. In 1963, the fund management contracts were changed, with a little persuasion from Mr. Pomerantz, and the change went into effect in 1963.

Starting at that point, sliding scales reflecting operating economies and the growth of the fund size were put into effect. At the same time all of the expenses of the funds, some of which had theretofore been assumed and paid directly by the funds, were paid by IDS out of the management fee, so that thereafter the management fee and the expense ratio has been identical.

In 1964, with the continued growth of the funds-greater growth than, I suppose, had been anticipated-negotiations with the committee representing the unaffiliated directors of the funds resulted in a new contract further reducing the management fee.

In 1966 another amendment was incorporated into the management contract to reflect the fact that IDS had acquired, through a subsidiary, membership on the Pacific Coast Stock Exchange. Provision was made in the contract to provide that the management fee would be reduced by an amount equivalent to the profit realized by the brokerage operation.

Now, giving the effect to these events, all of which have transpired, in the last few years, the expense ratios of the funds have dropped: in the case of Investors Mutual, from .54 in 1956 to .33 in 1966 ; or from $\$ 27$ to $\$ 16.50$ on a $\$ 5,000$ account (our average size), or 39 per cent. In the case of Stock Fund from .57 in 1956 to .36 in 1966 , or a dollar reduction from $\$ 28.50$ to $\$ 18$ on a $\$ 5,000$ account, a 37 per cent reduction. In Variable, which had its first full year of operation in 1958, the reduction in the expense ratio has been from .67 in 1958 to .34 in 1966 . The over-all average has been a 41 per cent reduction from .58 in 1956 to .34 in 1966, or from $\$ 29$ to $\$ 17$, on a $\$ 5,000$ account.

Now, I think that these figures evidence the fact that competitive forces are at work, and that the present structure does work. These last reductions occurred through extensive negotiations with a committee representing the unaffiliated directors of the funds. Perhaps I should mention that at IDS the funds have a president, a vice president and general counsel, and a secretary, three officers who are full-time officers of the fund, unaffiliated in any way with IDS.

I think these figures reflect the fact that competitive forces must be exerting themselves, or else IDS has become an eleemosynary institution, in which case we'll have a difficult time accounting to our own shareholders. These reductions have occurred because when we 
periodically sit down and look at the fee, and when the unaffiliated directors of the funds do so, we look at the other funds to see: what they are doing, what their expense ratios are and what they are charging. We know we have to take these forces into account, and if we don't take them into account, they are forcefully pointed out to us.

I'm sure that the other larger funds particularly, can demonstrate similar records. I'm sure that Joe Welch can with Wellington Fund. If I'm not mistaken, I think the expense ratio at Wellington Fund has dropped to around .34 .

So these forces do come into play. This is a competitive industry which reflects competitive influence in the negotiation and establishment of the management fee.

\section{Conflicts of Interest in the Mutual Fund Structure}

PRofessor MUNDheIM: I noticed that Abe was scribbling away furiously. I just wondered if that was because you had never heard so much praise coming from an industry source?

Mr. Abraham L. Pomerantz: I must say, I have been called less gentle things in the past than "trigger."

I enjoyed the accolade, although I think the praise, as always when coming from your erstwhile adversary, tends to be somewhat excessive, and even hyperbolic. I would like to go on because I think you set a nice note for me when in your opening remarks you distinguished the esoteric discussion of this morning from the hoped-for more monetary discussion of this afternoon. In the discussion so far there has been a lot of talk involving those slippery terms, "reasonable" and "fair." Defendant's fees are always fair, and plaintiffs say they are unfair, and to my mind this is an exercise in semantics which doesn't advance the polemic any.

My quarrel with Joe Welch, with whom I settled my litigation not so many years ago-and three other gentlemen surrounding me with whom I have settled cases-makes me feel that I am in the camp of the enemy, albeit very amiable enemies. I have settled my money dispute with you, but my ideological dispute carries on, Joe, and Al Jaretzki and Allan Conwill and Bob Loeffler, representing four different sets of malefactors of great wealth.

You know, Harlan Stone wrote-I guess, over a quarter of a century ago-and I'd like to put this problem in its broad frame of reference-that when the history of this period gets written-and Harlan Stone had a pretty good vantage point on this period-the greatest menace, the greatest evil, in our society-and these were 
measured, judicial terms-was the violation of an ancient Biblical precept that no man can serve two masters; ${ }^{21}$ and by extension-this is my editing of Stone-where there is conflict between self-interest and fiduciary duty, you and I know who comes out on top.

Now, this is about the birds and the bees of the American corporate scene; and of all dualities and of all conflicts on this scene, nothing-but nothing-approaches the open end mutual fund for incestuous relationships.

The fund is conceived by a bunch of people whom we call advisers or managers. "Manager" is a good shorthand term. This group gives birth to the fund. The fund is manned by the advisers. If I may carry on the figure of speech, the umbilical cord is never cut after birth, as would be true in ordinary biological life.

\section{The Unaffiliated Director}

The principal safeguard provided by the Investment Company Act, against overreaching by managers or advisers, is the so-called unaffiliated director, which means in plain English a presumably independent director, which in turn means that he is supposed to safeguard the public-he's a watchdog-against the human tendency of management to take as much as they can get away with, short of being caught by us cops, or triggers, or the SEC or someone else.

If I speak in rather unmodulated or brusque terms, you will forgive me, because I'm trying to communicate.

Who picks the unaffiliated directors? The affiliated men pick the unaffiliated men. The men who need to be watched pick the watchdogs to watch them.

Now, in its wisdom-and no sarcasm is intended-the statute has erected certain mechanical things which a man must avoid being in order to be an independent or unaffiliated director. For example, he mustn't own stock in the adviser. He mustn't be an officer or director in the adviser or manager or underwriter. ${ }^{22}$

But obviously, you know and I know that if you are choosing an unaffiliated director or an independent director you are not going to choose anybody who is going to be too hard on you. You are going to tend to pick a friend of yours; and may I say again, as a footnote, that in my litigation I have encountered two situations where a so-called unaffiliated or independent director happened to be the son of the leading stockholder of the adviser.

21 Stone, The Public Influence of the Bar, 48 HaRv. L. Rev. 1, 8 (1934).

22 Investment Company Act $\$ 10,54$ Stat. 806 (1940), 15 U.S.C. $\$ 80 \mathrm{a}-10$ (1964). An "affiliated person" is defined in $\$ 2$ (a) (3), 54 Stat. 791 (1940), 15 U.S.C. $\$ 80 \mathrm{a}-2$ (a) (3) (1964). 
Now, how funny can you get? And yet with straight countenance under oath the testimony was that the son was going to "call them as he sees them," to coin a phrase, and he was not going to be partial to his father.

All I'm getting to, in my usual long-winded way, is my quarrel with Joe Welch and with the rest of the men around here about free enterprise. I am in favor of free enterprise, and I'm in favor of democracy and all the other eternal verities, but when you have a situation which is so fraught with mischief, what is needed is more rather than less SEC supervision-or, to use that harsh word, "regulation." Remember this industry has $\$ 40$ billion of the public's money and roughly 4 million investors.

\section{The Argument That Stockholder Ratification Is Meaningless}

One of the recommendations for reform proposed by the SEC is that the court should not be bound by stockholders' approval or ratification of the fees under attack, in cases where the court finds them excessive. The recommendation is that when the trial judge appraises the fairness of fees paid to management, he may disregard the fact of stockholder approval or ratification. This is terribly important because every stockholder's action charging excessiveness that has gone to trial has been nonsuited or dismissed by judges who may have felt that the fees were excessive-but who felt bound to follow the presumed will of the shareholders expressed in stockholders' ratifications.

Here again we have theory in conflict with reality.

Despite all the disclosure required by the vigilant Phil Loomis and his SEC associates, it is a simple fact of life known to any sophisticated lawyer that stockholders' ratification can be had for the asking; it is not a real exercise in corporate democracy. I don't have statistics, but I know from my professional observation that when you put to shareholders the question of ratification or approval of a management contract, say, at page 43 of a 51 page proxy statement, as Resolution No. 4, sandwiched between some innocent-sounding resolution to increase capitalization and another resolution equally less than world-shaking, and then when you trot out the proxy solicitors to "bring out" the vote-you can get the stockholders to vote for almost anything you put before them.

I want, in closing this set of remarks, to suggest that the SEC's recommendation is not more than a mild corrective: the proposal would permit the court to make a judgment as to what is a fair fee unhampered by a ratification procured by the very persons who are using it to hold on to their self-awarded fees. 
Professor Munderim: Joe, we ought to come back and give you a chance to say a few words.

\section{Influence of the Unaffiliated Director}

MR. WELCH: First of all, I'd say that you're a pretty tough man to debate with, Abe.

Secondly, I don't want you, Abe, to get a swelled head over the praise you have had here this afternoon. For the record I want to make it clear that many funds had reductions in fees-meaningful reductions-long before any litigation.

Abe, I don't think you give nearly enough credit to the dedication of the independent directors in seeing to it that the shareholders are protected. If you would attend some of our board meetings, you would find that our life is not always pleasant. We give to our directors every month not only a record of what we have done as managers, but also we regularly give them our performance record against other comparable funds. Throughout the year we give them material on what other funds are charging for investment advice. We keep them fully informed; they demand that they be kept fully informed. And as I said before, I think these fellows are performing a very dedicated duty as independent directors.

Our fees, and many others, were reduced many, many years ago, and are continually being reduced as we grow in size. Not all of this is attributable to the independent directors, but certainly they are acting as watchdogs, and I agree with what Bob Loeffler has said. In his case there is a dramatic example of the distinction between insiders and outside watchdogs.

So I think that the role of the independent director is being criticized too much. I think they do a job, and I think they are going to continue to do a better job.

\section{The Position of the Commission Report}

MR. PHILIP A. Loomis, JR.: I would like to make some observations, which, as Frank pointed out this morning, may be heresy, upon what the other speakers have said.

I find myself agreeing in part and disagreeing in part with everything that has been said, and I think that the Commissioners' report, in effect, reflects that uncomfortable middle position.

As to what Mr. Herman had to say, he provided us and the industry and everybody else, with a convincing exposition, that a problem does exist; that the fees in the externally managed mutual fund field are somewhat higher than in other comparable forms of investment management-and I will not for the moment get into the 
dispute about whether pension funds are a comparable form or not. They are similar, but by no means the same.

He also showed-and this, I think, was one of the most striking things shown by the Wharton School Study-that the economies of scale that are available as mutual funds grow were not being passed on at that time to investors in any adequate degree.

We recognize that since then, due, perhaps, to Abe Pomerantz and to increased awareness on the part of independent directors-I think, not due to competition-there has been a greater tendency on the part of the larger funds to pass on these economies of scale, and to scale down the fees in a more meaningful way. However, as the Commission's report showed, this does not happen in every case, and in some cases it happens in a rather token way.

At the same time, to the extent that there is some overtone in Mr. Herman's remarks that the Commission should get into regulating fees in a scientific way-the report does not suggest that. The reasons why that was not proposed are, among other things, explained by Joe Weich. This is a personal service business for which rate regulation in any of its previously known forms does not exist, and should not exist.

Consequently, we go back to two things which are, I think, rather fundamental: First, as Joe Welch said, investment advisory fees should be reasonable. Everybody agrees on that. Second, as Mr. Pomerantz pointed out with considerable pungency, the investment adviser is a fiduciary to the stockholders of the fund. I don't think anybody denies that either. That means that he owes them a duty and a responsibility not only to perform as well as he can but to charge fees which are reasonable.

\section{Enforcing Standards of Fiduciary Responsibility}

It has always been the law that the charges made by a fiduciary to his beneficiary, at least where arm's length bargaining doesn't exist-and I think that none of you will contend that the mutual fund shareholder bargains at arm's length with the management over the fee-the law has traditionally stepped in to make sure that the standards of fiduciary conduct were observed.

Abe Pomerantz has pointed out some practical and procedural obstacles to the enforcement of that fiduciary responsibility under existing law-particularly the position that if the stockholders ratify, then the court has to find not merely that the fee is unreasonable, but that what is going on amounts to waste-misconduct of a gross sort-before the court will intervene; and the courts very properly 
do not wish to charge mutual fund managers, who are responsible and loyal people, with personal misconduct, breach of trust or waste of the corporate assets. Hence judicial control doesn't operate very well.

Nor does the Commission have a very effective weapon in this field. The Commission shouldn't go into rate regulation, but I think it is part of the Commission's function to endeavor to see that fiduciary responsibilities are observed.

I must take issue rather strongly with the suggestion in Joe Welch's remarks-and even more the suggestion in Mr. Shelley's memorandum - that the standard of fiduciary conduct here is fuily discharged if you are able to satisfy yourself that the individual shareholder couldn't do nearly as well if he had tried to run his own little mutual fund all by himself with his own $\$ 2,000$. Obviously that is true; he couldn't do it. But that doesn't mean that the fiduciary duty is discharged. This raises a very difficult problem in the law of fiduciaries. Everybody can see that when a person serves as trustee for a widow or an orphan, he's got to treat him fairly. The courts have and will step in to protect these people. But what of the obligation where, as Joe Welch has said, you are a fiduciary for 350,000 persons, to no one of whom your fee is more than peanuts?

Mr. Loeffler has pointed out that in the case of Investors Mutual, where I suspect there was rather more arm's length bargaining between the fund and IDS than generally goes on, they were able by a very difficult process of hard work to reach the point where the cost to the average stockholder was reduced from $\$ 27$ to $\$ 16$.

If I were an IDS stockholder, I don't think I would regard that by any means as the most important aspect of my investment. If I had $\$ 6,000$ at stake, I'd be more interested in how they performed; and this is the paramount reason why competition is not much of a factor in setting fees. The directors are more aware of their responsibilities, but they are likewise at a disadvantage even if they are more effective than Abe Pomerantz gave them credit for being, because they really have no alternative. They can't kick out the management in a dispute over fees. The stockholders would throw them out if they did. So here is a situation of fiduciary responsibility in which there is no effective means of enforcement.

I would view the various factors that were enumerated in the report, and in the Wharton School Study as guidelines for determining whether or not the standard of fiduciary conduct is or is not being observed. If it isn't, the courts, under the Commission's proposal, can perform one of their traditional responsibilities-to enforce this standard. 
But the Commission doesn't intend to get into rate regulation. All it will have to do is to determine, if Mr. Pomerantz doesn't arrive ahead of it, whether or not there is a situation which it should call to the attention of the courts. We think that, in view of the absence of other controls, the fact that there is a conflict of interest here, and that for various reasons the standard of fiduciary duty may not be fully or correctly applied, the Commission's recommendation provides a conservative means of dealing with excessive management fees in accordance with traditional procedures.

We are not going to become a rate-making body. Nobody is. We are not going to set rates with precision. They will continue to vary. We will give great weight to fairly exercised management judgment. And we will not focus on small things, and say fees should be .47 instead of .48 ; but we will provide a backstop which I think is needed.

I think that the bank common trust fund situation is, frankly, a red herring. Bank common trust funds do not appeal, nor are they intended to appeal, to small investors. They don't want the small investor (as I found when I was in private practice, and dealing with some family matters); they don't even want what I would regard as a pretty good size investor.

They tell you they have a different responsibility. The charges they make cover not only the administration of the common trust fund, but the assumption by them of a trustee's responsibility and a trustee's liability for handling an individual trust which is given to them and is placed by them in their common trust fund. They have to make sure that they are discharging their duties as trustee for the individual, as well as manager for the common trust; these are two different things.

I agree with Joe Welch that the directors and everybody else should give a great deal of weight to performance and to the question of whether the manager is performing the obligation he assumes. I don't think, as I have mentioned, that the fact that the individual investor can't operate his own mutual fund all by himself with $\$ 2,000$ has any relevance whatsoever, but I do feel that the Commission has devised a conservative and flexible device to meet a problem that sometimes arises, and which must necessarily be met for the protection of investors.

Professor MundHeIM: Alfred?

The Investment Adviser as Fiduciary

Mr. Alfred Jaretzki, JR.: The last thing in the world I want to do is to discuss law. I'm not really competent to do it, but when 
Phil Loomis keeps talking about the investment adviser being a fiduciary, I must ask him to be more precise.

The adviser to Wellington Fund, for example, is a fiduciary in so far as he manages the accounts of the stockholders, but he is not a fiduciary as far as his fee is concerned. There he contracts with the stockholders, and the stockholders are represented by the independent directors.

Now I agree that there is a question whether the stockholders are adequately represented by the independent directors, but that isn't the point. I insist that the adviser is not a fiduciary as to his charges to the investors.

The real issue here is whether the fees at present are reasonable, and I think with some justice it could be said that some of the fees are not reasonable. But the further question is: is it necessary or desirable to have the SEC interfere with those fees by litigation? Even where the fees are too high, I question the need to give such authority to the SEC.

Fees are coming down. I think that experience has shown that while Phil Loomis, the present General Counsel, would be very fair and reasonable; in general, investment company managers would find the members of the SEC staff in their hair from morning until night.

Professor MundHeim: Allan?

\section{The Power of the Unaffiliated Director}

MR. ConwILL: I have been sitting here listening to Phil Loomis say at least three times that the Commission is not interested in rate regulation. I heard Frank Wheat give us that assurance this morning. I suppose I should take some comfort from those statements; but I don't, because it seems to me that this so-called reasonableness test, as it is described in the report, involves, if not direct rate regulation, something very much akin to it.

And when I heard Frank this morning say that this is an area in which arm's length bargaining simply isn't possible, and when I heard Phil make equivalent statements this afternoon, I get very uneasy about a future in which I can foresee that the Commission's judgment, in what to me is a business judgment area, is going to be substituted for what I properly consider the role of the board of directors, and particularly the unaffiliated directors.

Now, the Commission representatives and Abe Pomerantz have made it perfectly plain that they think that the unaffiliated directors 
are, in essence, powerless. I don't believe that for one minute, and I would be remiss if I did not observe that the report does absolutely nothing to strengthen the position of unaffiliated directors. Indeed, it introduces a curious anomaly, because the recommendation is that once the fee arrangement is challenged in a court, the fact that the unaffiliated directors approved the management contract will not be considered relevant. ${ }^{23}$

Now, up to the time that I read the report, as an unaffiliated director, I thought I was a rather important man, because it seemed to me that when the statute required a majority of the unaffiliated directors to approve the management contract, it contemplated a significant act on the part of the unaffiliated director. But in reading the recommendation in the report, I find it's not so at all. In substance, when the matter gets to court, the unaffiliated director becomes the man who never was.

It seems to me that in talking about reasonableness, we are asking: is the management fee too high? And in determining that, a fundamental consideration to me is: what value do you get for your payment of the management fee? I think there is far too much emphasis on one-half of one per cent, or $3 / 8$ of 1 per cent, or whatever it might be. To me one-half of one per cent can be much too high. It also can be much too low.

For example, I have voted affirmatively to authorize a management fee which realistically amounts to more than one-half of one per cent, and I find on the basis of the closing figures yesterday that in a period of little over four years the per share asset value of that fund increased by 92 per cent. I'm glad I voted to authorize that management fee, because I think the stockholders got a bargain.

\section{The Argument Against Commission Intrusion}

I think Alfred Jaretzki really puts his finger on it when he says the basic question is whether there is a need for Commission intrusion. We all have opinions as to what might be too high, but the issue is: is the Commission in any better position to evaluate that than we?

If the recommendation in the report is adopted, the SEC will be in a much better position than we to make themselves heard on the subject, because the recommendation also authorizes them to go into court and make their views known to the court, which is not permitted to consider the fact that unaffiliated directors approved the arrangement. It also empowers them to adopt rules with respect to the factors which should be considered in determining reasonableness.

23 SEC Mutual Fund Report 144. 
Perhaps management fees in some instances are too high, but are they high enough to justify Commission intrusion? I believe it is a business judgment area, and I suppose, Bob, what in essence I am saying is that on the basis of what I have seen thus far in the reportand much as is my affection and admiration for the Commission and its staff-I am unwilling to have their business judgment superimposed upon mine and the business judgment of my director colleagues.

\section{Standards to Guide the Unaffiliated Director}

Professor Mundentm: Allan, your emphasis on the role of the unaffiliated director brings us to the question: What's a director supposed to do? How is he supposed to function? What standards is he to have in mind when it is time to negotiate management fees or advisory contracts?

Let me put a specific case. Suppose that an unaffiliated director of a very large externally managed fund says to himself: we can hire our own organization comparable to the one which serves us. Indeed, on a salary basis we can pay even more than the advisory company presently pays the investment research analysts and top management. In that way we can get pretty much the same advice and the same kinds of services, but for less. We don't have to worry about the stockholders of the adviser who may have bought their shares at a high price and now want a commensurate return.

Such a case might present itself because the unaffiliated directors presumably are aware of some of the larger internally managed funds, which have much lower expense ratios than most of the externally managed funds.

How do you answer that director? What are the standards that permit such a director to justify to himself that internalization is not the answer he must reach? Alfred?

\section{The Shell Theory}

MR. JARETZKI: The Investment Company Act recognizes and permits the organization of the externally managed fund, and such a fund has been organized and the stock has been sold to the public on that basis. I don't think that that's a question for the directors. That's the way it was sold, and even assuming that with a $\$ 1$ billion or $\$ 2$ billion fund you could get cheaper internal organization, that isn't what the stockholders bought, and I don't see that there is any requirement on the directors to consider changing the set up. 
Professor Mundheim: Morgan, do you want to talk to that? Morgan Shipman is a Professor of Law at Harvard Law School, and has done some work in connection with this report.

Professor Morgan Shipman: Yes. First, I should exlicitly disclose that $I$ am a consultant to the Commission on the report, and the other part of the Commission disclaimer must follow. I am, of course, more removed from the report than the Commission people; what they said certainly applies in my case: the views I express here are nothing more than my own individual views.

I disagree. It seems that $\mathrm{Mr}$. Jaretzki is espousing the shell theory-that an arrangement has been sold to the investing public over the years, and that the directors, unaffiliated or otherwise, have no right to terminate that arrangement. The Investment Company Act specifically rejects the shell theory. ${ }^{24}$ This lies at the heart of the management fee dispute. The Investment Company Act looks at the investment company as a separate legal entity, and the directors of the investment company have clear continuing fiduciary duties to the fund and its shareholders. This applies to the affiliated and the unaffiliated directors. Justice Cardozo made it clear almost fifty years ago in the Globe Woolen ${ }^{25}$ case that the director involved in the conflict of interest has the affirmative duty to step forward and ensure that the transaction is fair and reasonable to the corporation.

All directors have the fiduciary duty to examine the situation and to ascertain what is the best long-term continuing arrangement to make. If the adviser has done well over a period of years, this is something to be considered. Also to be considered are any losses the adviser may have suffered in early years when the fund was being built up.

So I think the first thing to do is to bury the shell theory.

MR. JARETZKI: I don't subscribe to the shell theory.

Professor Shipman: I'm sorry. I thought I heard overtones of it. You see, I strongly oppose the shell theory. Its adoption would weaken the concepts of fiduciary duty and impede progress.

From that point, then, I think the directors should also discard the idea that we look at the value of the service on a shareholder-byshareholder basis. We hear a lot of language today to the effect that: really, it would be a bargain to shareholders at many times the price; that they have been making a lot of money out of their investment in mutual funds-and this has been true during the past fifteen years.

24 Investment Company Act $\$ 15(\mathrm{a})$, (c), 54 Stat. 812 (1940), 15 U.S.C. $\$ 80 \mathrm{a}-15$ (a), (c) (1964).

25 Globe Woolen Co. v. Utica Gas \& Elec. Co., 224 N.Y. 43, 121 N.E. 378 (1918). 
MR. JARETZkI: I agree with you entirely.

Professor SHIpman: And I am in substantial agreement with the excellent articles that you have written over the years in this area. ${ }^{26}$

\section{The Power of the Directors to Internalize Management}

Professor Herman: If Mr. Jaretzki is correct that the Act does not contemplate that the board of directors will get rid of a management group, then, of course, their power over the management fee is thus made null and void, because they no longer have an ultimate sanction. If they cannot replace the management, then I think that a very serious crimp has been put in their capacity to negotiate a management fee.

Mr. JARETZKI: I didn't say that they could not replace a management.

Professor Herman: What did you say?

Mr. JARETZKI: I said that the 1940 Act contemplated an investment company structure with external management, and therefore I did not think it was a question for the directors to decide, whether or not they wanted an external management.

Professor Herman: I thought you were saying that it wasn't for them to decide whether the management should be replaced.

Mr. JARETZKI: Oh, no. I did not say that, and I did not mean that.

Professor Mundheim: Well, you are not saying, are you, Alfred, that the directors can't decide that they would like an internal management? Or are you?

MR. JARETZKI: Well, I haven't gone that far. I wouldn't go quite that far, but I would say that internalization would be a very radical step under the circumstances.

\section{Professor Mundheim: Bob?}

Mr. LoefFler: Well, I was going to address myself in part to that, although as has been said, I think the possibility of internalization is a form of the competition with which a manager of capital is constantly confronted.

26 Jaretzki, Duties \& Responsibilities of Directors of Mutual Funds, 29 LAw \& Contenr. Prob. 777 (1964); Jaretzki, The Investment Company Act: Problems Relating to Investment Advisory Contracts, 45 VA. L. REv. 1023 (1959); Jaretzki, The Investment Company Act of 1940, 26 WASH. U.L.Q. 303 (1941). 
Certainly, the unaffiliated directors of a fund in determining upon that course of action would entail a grave responsibility, because, basically, the shareholders have bought the management of the management company. If the unaffiliated directors undertake the responsibility of discharging the management company and running the fund themselves, they had better be successful.

But certainly they have that alternative available to them, and it's one form of the constant competition that is present, and it's not necessarily always an unarticulated one. These possibilities and alternatives do exist, and that, I believe, is a part of the reason why the management fees are coming down today.

\section{The Investment Adviser's Relationship to the Fund's Shareholders}

But I would like, while I have a captive audience, to get back to a difference that $I$ have with the view that was expressed previously by Phil Loomis. When Phil suggested that the management company has a direct fiduciary relationship to the fund's shareholders-who in effect are our customers-and that a management company's charges therefore must be reasonable, and that there is no arm's length bargaining with the shareholders, he equates the relationship, in a sense, to that of trustee and beneficiary. I think that he is legally wrong, and I think this is an important matter of substance.

To begin, the management company is engaged in a business, the business of managing funds; and it is a business. The management company does engage in negotiations-arm's length negotiations-with the unaffiliated directors of the funds, who are in that sense like union negotiators.

To say that the management company is in a position of a trustee for a beneficiary, with no arm's length negotiation with the representatives of the individual shareholder, is to pretend that the unaffiliated directors are not there at all.

I think that the Commission when it takes this approach is in an ambivalent position. It appears not to be able to make up its mind. The structure of the 1940 Act is there. We observe it. The present report endorses it; and yet the Commission tries to pretend it's not there, as though it can't make up its mind whether it relies on the 1940 Act structure or it does not.

I assumed this report endorsed the existing structure. Under this structure, the fund directors negotiate with the management company, which is engaged in the business of managing the funds, with respect to the price that will be paid to them for the services they are rendering. 


\section{Governmental Regulation of Profit}

Going one step further, because this is perhaps the sum and substance of it all, there is a question of principle that comes into play, whether this area is an appropriate place for the introduction into our economic system of the principle of profit regulation.

All that seems to be said, really, is: well, maybe the profits are too much. Maybe they are not; but maybe in some areas they are too much, or for some funds the profits are too much for the services being rendered. So we should undertake to regulate some of those profits.

Nowhere that I know of to date in our economic system have we ever introduced the concept of profit regulation in a nonutility industry which is neither a protected industry, nor exempt from the antitrust laws.

One example of the latter, I think the classic example, is the New York Stock Exchange minimum commission. Brokers are all permitted to get together and agree on a minimum price that they all will charge. Management companies cannot do that. Mutual fund management companies are not exempt from the anti-trust law. They are not a protected industry. They are not a utility, and I don't think they should be thought of as a utility because they are not. It's only in those areas that you have profit regulation.

Now we have, I think for the first time, the suggestion of introducing profit regulation into our economic system on the principle that maybe somebody thinks the rates are too high. What's the harm in someone having the power to say that they should be reasonable?

The question is whether you rely upon the normal forces of our economic system as it exists today, or whether you are going to substitute some regulatory process. At the moment I'm not even going to undertake to say whether we should introduce this concept of profit regulation into our economic system, whether it's good or bad, but I think the proponent of it has the burden of really studying the consequences that flow from its introduction, and I have seen no evidence of such a study having been made. It's just thrown out on a "well, why not?" basis.

I think the import of this is far-reaching. If profit regulation is appropriate in the business of fund management, why is it not appropriate for the manufacturers of automobiles, for the retail druggists, for any other area where the public has the same interest, in the sense of being able to receive a service or a commodity at a reasonable price?

I think this is the import of this novel concept, and that there has been no study of its consequences. 
Mr. ConwILl: May I only add briefly to that, Bob?

The proponents not only have the burden of proof here, but I again revert to the idea that this is an opinion area. So far as I am aware, legislation is really justified when there has been a demonstrated abuse-not opinion-and I don't see anything in this report that documents any kind of abuse, other than opinions that something may be in some instances too high.

Professor Mundheim: I saw a head shaking.

Mr. Pomerantz: Many things have been thrown up these last few minutes, beginning with the rather startling declaration that investment advisers are not fiduciaries, enunciated by Jaretzki, J., and a straw man attack on regulation-profit regulation-which I didn't find in the SEC report. If it's there, I have missed it.

I think we ought to get down to the SEC report, which we are here to talk about.

I think maybe it would be a good idea if the SEC had come out with profit regulation and said: No more than one-half of 1 per cent for the first $\$ 100$ million, and three-eighths for the next $\$ 500$ million, and so on, establishing a standard of ceiling values, which, I might say, would have a good deal of precedent in our society; but I won't elaborate that theme now.

But that's not what the SEC says. It merely wants to balance the game. It merely wants to unload the dice. It merely wants to say to the courts: consider the question of fairness of fees as a matter of "fairness", whatever that very elastic word may mean. But, assuming it has meaning, give to the courts the power to say what is fair and what is not fair.

And in that direction what Bob Loeffler calls regulation is not regulation at all. That is a perversion of words. It's merely saying: let's play the game fairly.

For example, let the SEC come in and bring a lawsuit-and I welcome them as a professional competitor, I might add. Don't permit the use of shareholder ratification to hobble the courts.

Bob, I don't see this bogeyman of profit regulation which you conjure up. I see only the SEC's effort to be the man in the middle, to try to work out some kind of a balance which gives to the courts the right to make an objective evaluation of what is fair.

\section{Fiduciary Duties of Directors}

Now, let me turn to Jaretzki's statement that there is no fiduciary duty resting on directors to make sure that fees are reasonable. 
Mr. JARETZKI: No. I said that an investment adviser was not in a fiduciary capacity as to the amount of his fee, not that it has no fiduciary duty. It has a fiduciary duty not to charge excessive fees.

The Duties and Responsibilities of the Unafriliated Director

Mr. Pomerantz: That dichotomy escapes me. Let me get back to Loeffler. Loeffler says the cordon sanitaire between the shareholder and the adviser is the unaffiliated director.

Mr. LOEFFLer: On the issue of the fee.

Mr. Pomerantz: I have had fourteen investment company cases and fourteen sets of depositions and/or cross-examinations of the independent directors, and in not one single case did any unaffiliated director ever respond "Yes" to this type of question: When your fund grew from $\$ 100$ million to $\$ 600$ million, did you ever give any thought to making a comparison between your half of one per cent fees and somebody else's fees?

No.

Did you ever give any thought to an internal management, $a$ la MIT?

No.

Did you ever once suggest that when the fund got to be over a billion dollars-in one or two of the cases I had-perhaps a reduction from one-half per cent to seven-sixteenths of one per cent, or any other minute fraction?

Answer: No-and I mean the uniform answer.

The answer is that the realities are, as the SEC's report well recognizes, that you can't count on the unaffiliated director. There's no point in condemning him and using harsh epithets. The fact is that in real life the unaffiliated director never has initiated a movement for a reduction of fees.

I don't want to overstate the argument. There have been times when fees have been reduced, but that's in spite of the unaffiliated directors. That's when, because of conditions, perhaps, of competition, or what have you, the management-the adviser-has determined that it would be good business to reduce the fee. That's not happened very often, but it has sporadically.

I have one case now-I will not name it-where the adviser also gets one-half of one per cent, and the fund has over a billion dollars in assets. The adviser also gets brokerage commissions-I'll soon be naming it, won't I?-of over $\$ 1$ million a year, and keeps them; gets 
a load of the usual $8 \mathrm{x} / 2$ per cent, and its net income before taxes on all those sources is $\$ 11 \mathrm{I} / 2$ million a year.

Now, wouldn't you imagine, speaking of Bob Loeffler's hypothetical unaffiliated director, that somewhere along the way some fellow would raise his little hand and meekly suggest that in the light of the vast growth of the fund and the accompanying fact that expenses don't go up proportionately with the rise in the assets of the fundthat some little, meek voice would suggest that maybe there ought to be a consideration-just, please, a reconsideration whether those fees ought to be reduced?

When I was a boy, that's how I was taught that the fiduciary obligation goes, and what it means.

There has been frequent suggestion that directors can't change an external adviser, because that's not the package which was bought. Of course, they can! And if there's any doubt about whether they should, they can always go to the shareholders and recommend it, and you know very well what would happen if the board of directors said: Gentlemen, we think we can give you the same type of advice for $\$ 5$ million less a year, or $\$ 4$ million less a year. I'm not a betting man, but I will give 2 to 1 that the shareholders would sign the proxies, and would be very happy to accept a new deal which is going to save them all that money.

So I think it's just a lot of rationalizing to say that, having gone into a mould, that that mould is so rigid that in the exercise of fiduciary responsibility the directors, affiliated or unaffiliated, can't reasonably consider and recommend a change.

I'd like to ask the rhetorical question: Who is there to protect the public, if the unaffiliated director cannot? Is it not the SEC in which is lodged the responsibility to try to assure some measure of reasonableness?

Much as I enjoy this business-and I'm not for a moment bemoaning it or claiming that I'm tired of it. I love it. I hope it keeps on another forty years. But taking a social view of the problem, the fortuitousness of finding a gambling lawyer-one who is ready to risk years of his time in the pursuit of this kind of suit where the penalty of failure is a great, great loss of time and money, although, true, the rewards of success are munificent-suggests that, with all due deference to the charming little references to my triggering, this is not the real solution to this very big problem.

Mr. ConwILL: Abe, I'm delighted that, with your usual candor, you have confessed that you enjoyed this work. I would add that with this new reasonability test you are going to enjoy it all the more. 


\section{Considerations in Deciding to Change Management}

MR. WELCH: I want to get back to your question as to what a board of directors should do in deciding whether or not they should change an external management for an internal management, or to hire somebody else. I think the directors, if the manager has been doing a competent job, would be hard put to make a decision to change just because of a matter of cost. For example, if the people they hire do a less than competent job, it's going to cost the fund infinitely more than the difference in managing fees.

These directors quite often are with you for years. They change from time to time, but they live with the manager, and they know his competence, and they also realize that the manager, as Morgan has said earlier, for a good many years didn't make any money at all.

Take our case. We formed Wellington Fund in 1929, which was a marvelous bit of timing. Eleven years later in 1940, we had grown to the enormous sum of $\$ 5$ million, and naturally we made no money. We lost money all through there. In another five years we were up to $\$ 15$ million, and we didn't make any money. We lost money.

It wasn't until we began to get some real volume in the late 1940's and the ' 50 's that the management effort became profitable.

Don't you think-don't all of you think-that the directors must give consideration to this long period of famine? And this isn't only true of our fund. Many had a hard time getting started. Isn't it fair that the management get the rewards of the many, many years of pioneering work in building the fund? And should it be considered an unreasonable fee when he begins to start to make some money.

\section{The Spectre of Rate Regulation}

My real problem is: Who is going to be able to decide any better than the independent directors what a reasonable fee is? I think they are in the best position to judge, based on what the manager earns and what they expect him to earn in the future. I'm worried about regulation. Although it may be argued that this isn't really rate regulation, I certainly think that it approaches it.

It seems to me that this is a job for the independent directors, and I do believe that in most cases-there may be some exceptionsthe independent directors are doing that job.

Mr. JARETZKr: The Commission is seeking rate regulation by the threat of litigation.

Professor Munderim: Phil, apparently you have not yet been successful in persuading the panel that we aren't in an area of rate 
regulation. Perhaps you can address yourself to that point. In addition could you comment on the point Joe Welch raised? In the Commission's standard of reasonableness, what weight may the director, or what weight would the Commission, give to entrepreneurial risk? Intrusion of that factor makes the standard of reasonableness very elusive. On the other hand, without some kind of guidance, the new test of reasonableness may not be much of an advance on the standards used by the courts today.

MR. Loomis: The report says that the contribution made and the losses incurred in getting a fund going should be considered in determining whether or not the fee is reasonable. ${ }^{27}$ As Bob says, that is not the easiest thing in the world to do, and I don't believe there is any mathematical formula for it, but $I$ think it is possible for the directors and for a court of equity to consider that matter and to give it weight-and considerable weight-but at the same time, that does not, I think, justify an unlimited right to exact fees over an extended period.

\section{The Fiduciary Duty of the Unaffiliated Director}

Now, it seems to me also that I have been misunderstood when I mentioned fiduciary relations. It may be, if you adopt a version of the shell theory, that you can say that the investment adviser as a legal entity doesn't have a fiduciary responsibility to the stockholders of the fund with respect to the fee. But I agree with Mr. Pomerantz that that is somewhat unrealistic. There is a slight inconsistency here.

It has been pointed out that the independent directors shouldn't, except under most extraordinary circumstances, get rid of the investment adviser, or internalize. This means-and this is, I believe, a fact of life in this industry-that the investment adviser is in effective control over the fund, and this is the way it is intended to be, in order that the stockholders can have the benefit of his advice. If he is in effective control of a legal entity, I think he owes a fiduciary duty to it in all aspects of that relationship.

Furthermore, the affiliated directors are directors of the fund. They owe a fiduciary duty to the fund, and I think that where they have, as Mr. Loeffler points out, a conflicting fiduciary duty to, say, the public stockholders of the adviser, they shouldn't neglect that duty either; but the existence of those conflicting fiduciary duties may give rise to a justification for the intervention of a court of equity, if they prefer the one master over the other. 
I think, therefore, that Mr. Loeffler's statement that the investment adviser is a separate business which has nothing more to do with, and no more responsibility to the stockholders than the printer does, misconceives the situation.

Mr. LOEFFLER: That is an overstatement of my statement.

Mr. Loomis: Well, I know. It is a slight overstatement, but I think that's where your last analysis logically leads.

Consequently, I do feel that there is a fiduciary responsibility here, and that you do have men serving two masters, and therefore, there is a basis for the courts to apply fiduciary principles.

\section{Potential Liability for Unaffiliated Directors}

Professor Mundheim: One question came up from the floor which seems very relevant at this point.

"Won't the standard of reasonableness impose such a burden of potential liability on independent directors that it will be difficult to get qualified men to act as such?"' In other words, the question says: in saying that the standard of reasonableness ought to be applied, why is it necessary to impose liability, or suggest liability be imposed on unaffiliated directors, who, the report itself suggests, don't have a great deal of power?

Mr. Loomis: I think the report endeavored to make it clear that independent directors would not have any personal liability, even if a court should determine that the fee was unreasonable. Certainly, if that's not clear, it should be. We don't intend that they should be subjected to financial responsibility for their acts, even if they are not able, or as Mr. Pomerantz has suggested, are unwilling to deal with the problem. I just don't think they should or will have any personal financial liability.

\section{Effective Power of the Independent Director}

With respect to the independent directors it seems to me unrealistic to say that the independent directors set the fee. They don't, and they can't. What they do is consider the fee proposed by the investment adviser, and analyze it to see whether they think it's reasonable. If they don't think it's reasonable, what can they do about it? They just have the power to say: Well, we think you are charging too much. And the adviser says: I don't think I am. I'm in a separate business-and there they are.

They are not in a position to say: All right, Adviser, if you don't come down, we're going to throw you out, because this is an extraordinarily drastic step which they can't and don't take in a disagreement 
as to the fee. Therefore I think it's just plain wrong to say that the fee is fixed by the independent directors. It's fixed by the adviser, subject to the approval of the independent directors, who should and, hopefully, in most cases, do what they can about the situation.

Professor Mundheim: Bob, you wanted a minute.

MR. LOEFFLER: Well, I wanted to clarify one thing with respect to the fiduciary duty concept that we were discussing. The fiduciary obligation with respect to the management company's fees-and I'm speaking in a technical legal sense-goes from the unaffiliated directors of the fund to the fund's shareholders-that is the line of the fiduciary obligation. Certainly there is a fiduciary duty-I don't know whether there is in a technical legal sense-in all other respects of the management of the fund.

Every management company feels a heavy responsibility for the welfare of the fund's shareholders, or to its customers, and certainly in today's business climate I think that's true of almost every enterprise with respect to the customers for its products.

Professor Mundheim: You are suggesting that the affiliated directors don't have an equal fiduciary duty on fees to the fund's shareholders?

Mr. LoEFFler: They don't vote.

Professor Mundheim: They have no participation?

Mr. LoEFFLer: They do not vote.

Mr. JARETZKI: I don't think they have an equal responsibility, because, as you say, they don't vote; but they do have a responsibility not to charge exorbitant fees.

Mr. Pomerantz: Well, actually they do vote, but what you mean is that the vote of the majority of the unaffiliated is necessary.

Mr. LoefFLer: As a practical matter their votes do not count. ${ }^{28}$

28 The Investment Company Act $\S 15(c), 54$ Stat. 813 (1940), 15 U.S.C. $\S 80$ (a) -15 (c) (1964) provides:

[I] t shall be unlawful for any registered investment company having a board of directors to enter into, renew, or perform any contract or agreement, written or oral ... unless the terms of such contract or agreement and any renewal thereof have been approved (1) by a majority of the directors who are not parties to such contract or agreement or affiliated persons of any such party ....

Section 15(a), 54 Stat. 812 (1940), 15 U.S.C. $\$ 80(a)-15$ (a) (1964) provides:

[I]t shall be unlawful for any person to serve or act as investment adviser of a registered investment company, except pursuant to a written contract, which contract ... shall continue in effect for a period more than two years from the date of its execution, only so long as such continuance is specifically approved at least annually by the board of directors or by vote of a majority of the outstanding voting securities of such company .... 
Mr. Pomerantz: At any rate, they have a fiduciary duty as directors not to waste corporate assets.

$M_{R}$. ConwiLl: Before we abandon the point I just want to object very strenuously to the concept that the unaffiliated director has no power. He has a lot of power if he chooses to act-and many times he does.

I think when Phil says that they don't have any power and it's impossible for them to act, he is basing that conclusion on the idea that so often management fees have not been reduced, and on the assumption that the management fees should be reduced. With respect to the funds on whose board I serve, I don't believe they should.

Mr. Pomerantz: What is the duty of the unaffiliated director, if not to supervise the fairness of the renewal of fees? Otherwise you are completely sterilizing him.

Mr. Conwill: All right, Abe. Certainly they have that duty if the adviser is not performing well, but-

Mr. Pomerantz: No. I'm not now raising the question, Allan, whether or not in a given context fees should or should not be reduced. I'm debating with you the question of whether there is a continuing fiduciary duty on the unaffiliated directors to see to it that the fees never get so large as to constitute, again, that vague conception of law, a waste of corporate assets.

Mr. ConwILL: Certainly there is a continuing duty of the unaffiliated directors to see that the fees do not get so large as to constitute a waste. There is a continuing duty for him to see that the stockholder has been treated fairly; but the fact that the fee has not been reduced does not at all suggest waste, and it does not at all suggest that the stockholders are not being treated fairly.

Mr. Loomis: May I mention one thing, because it has been repeatedly stated that $I$ have said that the independent director has no power. That is not what I mean. He has a certain amount of power. He can endeavor to persuade, to convince, whenever he feels the need to do so.

On the other hand, I do say that he is not almighty. He doesn't have all power. He only has some power. $\mathrm{He}$ is probably reluctant to exercise that in a vigorous way, because, after all, it's unpleasant to tell the people that he has worked with for years and likes and respects-and probably that's the only reason that he's on the board; he wouldn't accept the job if he didn't like and respect themthat they are charging too much. 
Nevertheless, if he feels so, he has some power, but in the last analysis his powers are limited, and his opportunities and perhaps his willingness to exercise them in a vigorous way may be even more limited; and, therefore, there is need for an additional check. But there is by no means any desire for price or profit regulation.

\section{The Difference Between Unreasonableness and Waste}

Professor Mundheim: Let me just try here to sharpen up one issue.

I sense agreement that all directors have a duty to see that no fee is charged which constitutes waste. I take it the Commission's position is that the director's duty is to see that no fee is charged which isn't reasonable-and if the duty is performed inadequately, then the court ought to be able to review it at the initiation of the Commission. What I would like to know-I have never been able to discover this answer in the course of discussions with my corporation law classes-is: What's the difference between an unreasonable fee and a wasteful fee? Can I get some help from Harvard Law School?

Professor Shipman: You can try.

First, a preliminary comment. Several times today it has been stated that the Commission has a horrendous burden in bringing this conflict of interest regulation into the Investment Company Act; that it's something quite foreign to that Act. It's not foreign at all. If one turns to Section 17, one sees that transactions between advisers and other affiliated persons and funds with respect to property are regulated, and that such transactions are not just subject to challenge in court: One must go to the Commission and obtain a determination that the terms are reasonable and fair and do not involve over-reaching on the part of any person concerned.

Your question ties in with Section 17. I think reasonable means that you construct a model of what the price would be in a purely arm's length dealing. Waste is, I think, on the other hand, something that might best be called grossly unreasonable. The Investment Company Act makes distinctions like this several places by using the adjective "gross" in front of certain terms. ${ }^{29}$

So, like all great legal debates, it's a matter of degree, as I have always looked at it, and something that is "waste"-especially the way the Delaware courts apply that test ${ }^{30}$-is something that is grossly unreasonable.

29 See Investment Company Act $\S 36,54$ Stat. 841 (1940), 15 U.S.C. $\$ 80$ (a) -36 (1964) which uses the term four times.

30 See, e.g., Saxe v. Brady, 40 Del. Ch. 474, 184 A.2d 602 (Ch. 1962). 
Professor MundheIM: How great is the distance between unreasonable and waste? How far has the Commission moved? Maybe the man to answer that is Mr. Pomerantz, since he's the man who normally has to meet the burden of proving waste under the present law, and who, if the Commission's recommendations are adopted, would merely have to meet a standard of reasonableness.

Will the recommendation make your job easier?

Mr. Pomerantz: At the expense of sounding as if I am antisemantic, let me dissent from my learned brother from Cambridge. It ain't all that complicated. It's this simple.

If a corporation can buy a locomotive for $\$ 10,000$, and the directors authorize the payment of $\$ 10,001, a$ fortiori where they are the sellers, that is (a) unreasonable, (b) waste, (c) actionable and (d) the directors ought to be condemned for it. There is no such semantic separation.

A director's duty in simple words-and we lawyers have a habit of making words very unsimple-is to see to it that the shareholder gets a fair shake, gets a fair deal; and whether what you are buying, Bob, is advisory service or locomotives or safety pins, it is the director's duty to get the best deal he can for his shareholders.

Now, at this point, enter the devil. If it's an arm's length trade with Baldwin Locomotive, or some arm's length advisory organization, like Ebasco, then, sitting as a judge now, I would be disposed to take a very tolerant, patient and forgiving view of the stupidity or incompetence of a director in paying too much. When I say "I," I mean every judge on the American bench, because my experience teaches me that judges are not punitive, and so many times we have seen situations where the judge shakes his head and says: Oh no! That was pretty dumb! But he won't impose a liability for that, because he's a human being.

Now consider the situation where the recipient of self-conferred largesse is the fiduciary. Then it is not only common sense but it is common law that the court must put the microscope to that deal, and put the burden-not only the burden of going forward, but the burden of proof-on the fiduciary to justify that transaction. Note the wholly different pragmatic approach of the courts to the recognition of the fact that when you are dealing at arm's length, the court will give you a great latitude of forgiveness; if you are dealing where self-interest is put in conflict with your fiduciary duty, then the courts will wag their finger at you and apply a stern rule. ${ }^{31}$

And it's as simple as that. It's simple, and yet complex, because, of course, the issue of what's fair is what tantalizes a court, and that's 
one of the reasons why, at the expense of starting off a whole new balloon, which I hope it doesn't do, if I were writing the SEC report, I would tend to relieve the courts of this very difficult burden-courts are not equipped to determine these commercial questions of fairness -and give it to an agency like the SEC, to establish the guidelines.

\section{The Argument That the Commission Proposal Constitutes Rate Regulation}

Mr. Loeffler: I have had arguments with several of my colleagues about the meaning of the term "waste," and the difference between "waste" and "reasonableness." This goes to the question as to whether this is or is not profit regulation. Reference was made by Morgan to Section 17 of the Investment Company Act, where the Commission already has jurisdiction to determine matters in a selfdealing situation. When you go into a court in a self-dealing situation, you don't have a waste problem at all. What we are talking about here is a situation where you have independent, unaffiliated directors, not engaged in a self-dealing transaction, exercising their judgment in good faith by entering into a contract which they believe is reasonable. Now under the proposal, when you go into court, you disregard the director's actions. The court is directed-not merely authorizedunder the recommendation, as I read it, to substitute its business judgment for that which has been made in good faith by non-self-interested directors.

To me this is a novelty in the law and in our economic system. The courts have traditionally been reluctant to substitute their judgment for the business judgment of directors of a corporation, absent fraud, self-dealing or something which invalidates the director's judgment or the contract.

The present recommendation directs the judge, or the Commission, (whichever it may be) in effect, to take over a function which has heretofore been performed in our economic system by directors of corporations.

I think that when a proposal such as this has been made, there is a heavy burden on somebody to say: We have made a study of what the portents and consequences may be. And I don't think that has been done here.

\section{The Argument That the Commission Proposal Does Not Constitute Rate Regulation}

Mr. Loomis: May I say a little about that?-because this illustrates one of the more difficult phases of what the Commission is proposing. 
It has been suggested that we are proposing that the courts completely disregard the judgments of the unaffiliated directors when they are arrived at in good faith. I don't think we are doing anything of the sort. As Abe Pomerantz has said, this is a self-dealing transaction, normally, because the affiliated directors are interested on both sides of it. The adviser is interested on both sides of it.

Normally, as Abe has said, this would mean that the courts would examine this through a microscope, and the party to that contractthe adviser-would have the burden of justifying it. But the Commission has not said that, because we recognize that the unaffiliated directors are there, and that they have a responsibility, that they are presumed to have discharged it to the best of their abilities.

Consequently the Commission, or Abe Pomerantz, attacking a fee under our proposal, will have the burden of proof. The fact that the unaffiliated directors have had an opportunity to act will in effect shift the burden of proof in what remains a self-dealing transaction; but we recognize that the unaffiliated directors are a minority of the board, that they are under certain handicaps, because they can't change the adviser, and that they don't like to pick a fight with the adviser. Consequently, we don't afford conclusive weight to the judgment of the unaffiliated directors, because we know that they are not exclusively in control of the transaction.

MR. JARETZRI: I think I owe it to Brother Loomis to say that I do agree with him about the unaffiliated directors being somewhat handicapped; but the question is whether that justifies taking the problem into court or taking it to the SEC.

I think, by and large, things will work out. There are management fees that are too high. There may be fewer such fees now than there were before, and I think they will find their own level. I just don't think the remedy suggested is necessary.

\section{Performance and the Management Fee}

Professor MUNDHeIM: I want to raise one other point, which many questions from the floor raise. To what extent, in thinking about the structure of the management fee or its size, should performance be taken into account, and on what basis should performance be taken into account?

Allan, I know that at least one of the funds in which you are a director uses a performance-related standard for measuring fees, so I suppose you think a good deal of weight ought to be given to that factor. 


\section{The Argument for the Performance-Related Management Fee}

Mr. Conwill: I think so. Indeed, given a free choice, I think a performance-related management fee is a fairer fee than one-half of one per cent, three-eighths of one per cent, or any other fixed percentage of the total assets, and I think performance should be given very great weight indeed.

I can cite you one example in which I actively participated, which to me reflects the power of unaffiliated directors, because the performance was, in the minds of the unaffiliated directors, inadequate. We didn't suggest that the management company have its contract terminated, but, because of our suggestions, there were changes of the investment personnel in the management company, and happily they turned the performance around, so that now it has a very satisfactory performance.

Now, what is the role of the unaffiliated director at that point? Since that date the assets also have grown. There has been no reduction to take advantage of the so-called economies of size, although they are there; but are the unaffiliated directors in that instance, once the adviser has made changes in accordance with their wishes, and once performance is highly satisfactory, to say: Now that you have done what we wanted, we are going to reduce your management fee? I think not.

The investor in a mutual fund should have a performance objective of some sort. That is, he may prefer to take the lesser risk of a balanced fund, or he may want to take a flyer with the so-called "hot" performing funds; but whatever the performance objective is, the extent to which the fund measures up to that objective is a critical factor in determining the amount of the fee. If the fund measures up to that objective, I do not think it is mandatory to take advantage of the economies of size.

Professor MundHeIM: Do you relate the amount of the fee to a particular performance; for example, performing better than the Dow Jones Average by one point increases your management fee by 10 per cent. How do you work that out? What time periods do you look at? One year? Or moving averages over a period of years? What penalties do you impose on somebody who performs less well, for example, than the average of all funds?

Mr. ConwILl: I have an active participation in several funds in which the performance is measured, and the fee is measured, by a fixed percentage of the amount of realized and unrealized appreciation of the fund, coupled with a one-year loss carryover, so that if 
the performance is very good, the adviser will earn far more than onehalf of one per cent; if the performance is poor, he will earn zero, and he will also have to carry the loss for that year over to the following year.

Also I have had participation in a management fee arrangement whereby the fee is based on the degree by which the performance exceeds a given average. I have been a little distressed to find in the so-called technical recommendations by the Commission, some of which are not technical at all, that at least some performance types of compensation would be outlawed. ${ }^{32}$

\section{The Argument Against a Performance-Related Management Fee}

Mr. JARETZkI: Mr. Chairman, I'd like to say that I think there is a little difference of opinion here. I think that's a rather dangerous method of compensation. I think it encourages speculation.

I can't say it's bad if people want that in a particular fund, but, as you know, the vast majority of funds don't do it, and I think they are sound in not doing it. I feel rather strongly about that.

Professor Mundheim: Do you have a thought on that, Morgan?

Professor ShIpMan: I would tend to agree with Mr. Jaretzki.

Mr. Loomis: I think we would tend, or at least some of us, to agree with Mr. Jaretzki, and that may be one reason for the suggestion that Allan is worried about.

Professor Mundererm: From an economist's point of view, doesn't Allan's suggestion that fees be related to performance, to achievement of objectives, make a great deal of sense? And from an economist's point of view, can you devise a system which perhaps will allay some of the fears with respect to speculation which Alfred and Phil and Morgan raise?

Professor HERMan: Well, it really would be extremely difficult for the independent director to arrive at a system of performance measures that would be very meaningful. The variation in performance by time periods and by type of fund is so complicated that I would think this would really present immense difficulties. You could have very drastic fluctuations in compensation that, really, I don't think would be based on anything very sound.

I should mention that we actually made a study, as you know, of the relation between performance and management fee rates over 
an extended period of time, and we found no correlation whatsoever between the two.

Professor Mundheim: If Allan's system were adopted, there would be one.

Professor Herman: Not necessarily. On the other hand, I would agree that the fund directors theoretically ought to be giving continuous weight, as Mr. Welch has emphasized, to performance; that the management fee rates and the cost of doing business are only one factor, and that performance is very important. It ought to be given some weight as a going proposition.

Therefore, there is no reason whatsoever why the fee rate can't be adjusted, or why, in fact, the independent directors couldn't decide that the management had performed so badly that they ought to be dispossessed and a new management put in-which I do not believe has ever happened in the mutual fund business.

\section{Measures of Performance}

MR. Conwill : Ed, you surprised me a little bit by suggesting that the unaffiliated directors would have difficulty finding performance measures, because the Wharton School Study itself drew many conclusions relating to performance, and it didn't seem to have any difficulty finding adequate performance measures. ${ }^{33}$

Professor Herman: The study certainly did not establish a standard that any member of the industry accepted. Every member of the industry was furious, and gave 400 alternative ways of measuring performance.

MR. WELCH: I said earlier, as Ed has alluded to just now, that one of the things that directors should give great weight to is how well the fund has performed under the manager's guidance with respect to its specific objectives.

Now, I think these are appropriate in a fund that has, perhaps, a single objective, such as Bob Doran spoke of this morning, which is much easier to measure than a fund with varied objectives. Bob's fund has one objective, to achieve maximum capital growth. They have a fee of half of one per cent, and if they fail to match the Dow Average, they lose an eighth of one per cent, and if they better the Dow Average by-I think it's two per cent-they get an extra one-eighth of one per cent.

I wouldn't advocate that that type of fee arrangement be put on that general type of mutual fund, but I do think that the performance of

33 Wharton Report 294-312. 
the fund in the light of its particular objectives is something that directors should give great weight to when making a fee.

And when I said earlier, Phil, that I think the many years of famine in the early years of funds would justify some profits in later years, I didn't mean that there should be an unlimited compensation for an unlimited number of years. As I said at the very beginning, I think fees should be reasonable, and should be reduced in amount.

MR. Loomis: I think we are in entire agreement on that.

\section{The Question of Reducing the Fee for Poor Performance}

Mr. Pomerantz: Joe, has there ever been a case in history when a fund has reduced the fee because of bad performance?

MR. WELCH: I don't think that's the remedy, if the performance is bad.

Mr. Pomerantz: Oh, you want to reward the good performance?

Mr. WELCH: You've got to do something about getting better performance, which is more important than the rate of the management fee.

Mr. Pomerantz: Well, we all agree with that, but what's sauce for the goose is-

Professor Herman: You get a new manager.

Mr. Pomerantz: Well, I would think, if you are going to have a system of rewards, the connotation is that the system, to use a harsh word, have punishments, or the opposite of rewards, whatever it is -demerits.

There is a fund that's getting paid $\$ 5$ million or $\$ 6$ million a year-and I could mention names, but I won't - and turns up over a rather long period of time a rather miserable performance record. In all fairness, the directors ought to give thought to lowering that fee, because $\$ 5$ million is a lot of dollars a year for advice which turns out to be, however unluckily, bad advice.

MR. WELCH: Isn't it more important, Abe, that the directors see to it that the manager hires some new people to improve the performance, as I think Alfred said here earlier?

Mr. Pomerantz: Oh, I'm not against that. I think they should hire new people, and they should lower their fees, and when and if the new people play better ball, they should get better rewards. 
You know, the old American system is the bonus system. This was before income taxes made it fashionable to convert bonuses to stock options, both of which have the same general thrust. Reward the good worker for his service by giving him very special extras over and above his compensation. I am for that-and to be fair to him, give him fair compensation to begin with, so that you don't punish him even if he has bad luck; I mean, have a floor underneath him and then give him incentive in the form of bonuses without end.

But it does seem to me that the investment company fellows have for the first time introduced this brand new concept of giving management a percentage of brick and masonry, that is, of all assets, without regard to whether they are making productive use of them. This is a brand new conception: if you are big enough, your reward goes to you merely because of your size, even though your investor may be suffering great losses, or not making profits, and I think conceptually, philosophically, that's a completely wrong approach. 